\title{
Integrated Control of Potato Pathogens Through Seed Potato Certification and Provision of Clean Seed Potatoes
}

\author{
Kenneth E. Frost \\ Department of Plant Pathology, University of Wisconsin, Madison \\ Russell L. Groves \\ Department of Entomology, University of Wisconsin, Madison \\ Amy O. Charkowski \\ Department of Plant Pathology, University of Wisconsin, Madison
}

Vegetative plant production plays a large role in food production worldwide. Most major nongrain starchy food crops and most fruit crops are vegetatively propagated, meaning that plants are propagated by planting rhizomes or tubers, or by making nodal stem cuttings in nurseries or tissue culture. One of the largest impacts that biological research has had on food security over the past century has been in production of vegetatively propagated fruit and vegetable crops. However, unlike the impact of the green revolution on grain production, reaping the benefits of research-based fruit and vegetable production relies as much or more on community-supported sustainable plant propagation and certification systems than on modern fertilizers, pesticides, and plant varieties.

One of the main goals of plant certification programs is to limit disease incidence in planting material to levels below a threshold that causes significant losses during production. Vascular bacterial, viral, and viroid pathogens are easily spread through vegetative production, and many of these pathogens can severely limit yields. Once a plant is infected by a vascular pathogen, all subsequent progeny from that plant have a high likelihood of being infected, which reduces yield and quality for all subsequent plants generated from the initial infected plant. There are no curative methods for vascular bacterial, viral, or viroid pathogen infections in plants that can be used on farms. Over the span of a few years, typically $100 \%$ of the progeny from vegetatively produced crops will become infected with yield-limiting pathogens in the absence of inspections to remove infected plants and without a continuous supply of clean planting stocks.

Effective production of vegetatively propagated crops requires healthy planting stocks, which are typically maintained in tissue culture or nursery planting blocks. Almost without exception, the healthy planting stocks for the major vegetatively propagated crops, such as potato, sweet potato, cassava, plantain, and citrus, are maintained by government agencies, nonprofit organizations, or grower cooperatives. Unlike with true seed crops, such as maize and soybean, large corporations do not invest in, produce, or sell planting material for vegetative fruit and vegetable crops to farmers. The exception to this rule is if the crop is transgenic, such as transgenic sugarcane, or if a corporation controls the entire production process, from variety breeding to sale of the product, which occurs with banana, pineapple, and potato in some markets. As a

Corresponding author: Amy O. Charkowski,

E-mail: acharkowski@wisc.edu

* The $\boldsymbol{e}$-Xtra logo stands for "electronic extra" and indicates that a supplemental methods file is available online.

http://dx.doi.org/10.1094/PDIS-05-13-0477-FE

(C) 2013 The American Phytopathological Society result, unlike with major true seed crops, breeding and propagation of planting material for vegetatively propagated staple crops remains largely in the public domain.

Seed potato production in Wisconsin is an example of production and certification of planting material for a staple crop remaining in the public domain for a century. In this article, we examine the development of this program and discuss factors that affect its sustainability. We also examine historical data that document trends in disease control over time and correlate these trends with changes in pathogen epidemiology or crop management practices and discuss possible future challenges.

Seed potato production: A history of cooperative translational research. The Wisconsin Seed Potato Certification Program (WSPCP) has been in existence since 1913, and its purpose is to certify seed potatoes against varietal mixture and disease incidence. The program was developed as a collaborative effort between Wisconsin farmers and University of Wisconsin faculty, with initial work on program development reaching at least as far back as 1905. Two crops were inspected in 1914 and 1915 at the expense of the University, and afterward the program was supported by fees. The WSPCP is still managed through the University of Wisconsin-Madison Department of Plant Pathology, and it is headquartered in Antigo, WI, which is the primary seed potato production area of Wisconsin. This program uses inspection protocols described in the Wisconsin Department of Agriculture, Trade and Consumer Protection state rule ATCP156.

In addition to certification, the University of Wisconsin has owned and operated a seed potato farm since 1941. The current farm, the Lelah Starks Elite Foundation Seed Potato Farm, was established in the early 1980s and is located in an isolated area near Rhinelander, WI. The Starks Farm was purchased with donations made by Lelah Starks, a local seed potato farmer. Ms. Starks was the daughter of Leonard Starks, who was a farmer responsible for much of the agricultural development in the Rhinelander area in the late 1800 s.

Seed potato production at the Starks Farm is an example both of the efficacy of translational agricultural research and of the impact that a farm closely tied to research activities can have on regional production. The close ties between university faculty and production at the Starks Farm allow implementation of new methods of integrated disease and pest management protocols for production of disease-free seed potatoes as the methods are being developed. It also aids in demonstrating that new disease control and production methods are feasible at the farm level and thus aids in implementation of these methods by local farmers. For example, the Starks Farm system allowed implementation of tissue culture propagation from virus-free plantlets, multiple forms of potato production in greenhouses, pathogen-indexing protocols, sanitation practices, and other pest management practices that aid in disease 
control. In recent years, the Starks Farm has produced 22,000 to 33,000 hundred weight (cwt) of seed annually, which is sufficient seed to plant 1,100 to 1,600 acres. Over $90 \%$ of the seed for publically available potato varieties grown on certified seed potato farms in Wisconsin originates from the Starks Farm.

Current seed potato production methods. In North America, nearly all seed potato varieties are maintained as disease-free tissue culture plantlets (46) (Fig. 1). Initial planting stocks are produced by multiplying the tissue culture plantlets through nodal cuttings. Tubers are produced from these plantlets in greenhouses, and these tubers, known as minitubers or nuclear stock, are planted into the field for the first field generation. Potatoes are then multiplied in the field, typically for 3 to 7 years, by seed potato growers, and then sold to a second set of farmers who produce a crop grown for fresh or processed use. In many countries, including the United States, potatoes grown for seed are inspected and certified to ensure no varietal mixture and low disease incidence by grower, state or national agencies (46). Although details differ among certification agencies, after inspection, seed potato lots can fall into one of three main categories: foundation class, which is suitable for planting on a seed farm; certified class, which is appropriate for use on a commercial farm where the tubers produced are destined for fresh market or processing; or rejected, which means the tubers are unsuitable for seed, generally due to high disease incidence or varietal mixture.
Historically, four viruses, Potato leafroll virus (PLRV), Potato virus $S$ (PVS), Potato virus $X$ (PVX), and Potato virus $Y$ (PVY), and a viroid, Potato spindle tuber viroid (PSTVd), have been important disease agents considered to be problematic pathogens limiting potato production and trade. More recently, PVY, PVX, and PLRV are on a list of plant viruses considered to be the most economically and scientifically important (36). PLRV is a polerovirus that is persistently transmitted by a few species of potato colonizing aphids, and it causes a characteristic leaf roll symptom that is easily identified visually (43). PVS is a mechanically and aphid-transmitted carlavirus that causes mild or no symptoms on most potato varieties (12). PVX is a mechanically transmitted potexvirus that causes mild or no symptoms on most potato varieties (38). PVY is an aphid-transmitted potyvirus that can cause mild to severe leaf mosaic, leaf drop, and stunting symptoms on several potato varieties (14). PSTVd is mechanically transmitted and causes distinctive foliar and tuber symptoms (30). Prior to the mid-1990s, the bacterial pathogen Clavibacter michiganensis subsp. sepedonicus was an additional constraint on potato production in the United States (9). This vascular pathogen, which is responsible for the development of potato ring-rot disease, can remain latent in potato for up to 4 years, quickly spreading among farms on contaminated equipment and through sale of infected seed potato stocks $(22,28,44)$. The disease still occurs sporadically in North America and Europe and remains a significant problem in Eastern Europe.
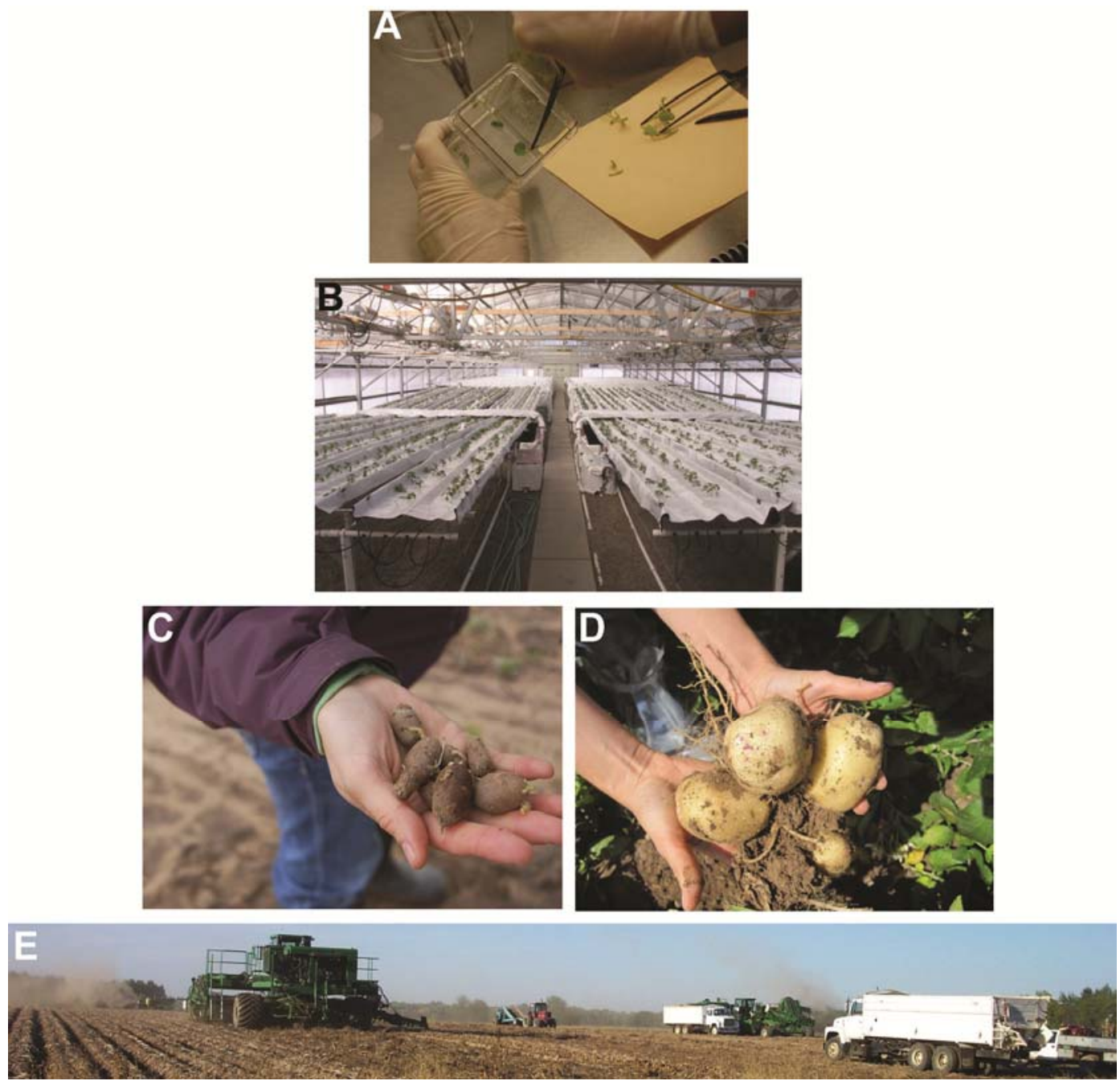

Fig. 1. Commercial seed potato production can be represented as a triangle starting with the output of a small number of tissue culture laboratories (A). These labs produce potato plantlets for greenhouse production of seed potatoes in pots or hydroponic systems (B). Eight to 10 tubers are typically harvested per square foot of greenhouse when pots are used, while 100 or more tubers can be grown per square foot in hydroponic systems. The harvested tubers, known as minitubers (C), are planted into fields on a small number of early generation seed potato farms. Typically, each plant grown from a minituber produces four to six tubers (D). The harvested tubers are typically multiplied on these and other seed potato farms (E) for another 3 to 5 years, with approximately 10 tubers per plant produced, before being grown to harvest tubers for consumption. The progeny of tissue culture plantlets produced this year will not reach consumers for four or more years. 
Of the potato diseases that seed potato farmers encounter, disease caused by PVY infection is now the most common reason for rejection of seed potatoes from certification in the United States and Canada (14). Although PVY can be spread long distances by numerous species of dispersing aphids, the most important inoculum sources for PVY transmission are infected potatoes within or near a potato field (33). Thus, disease-free planting material is a critical first step in limiting the spread of PVY. In addition to planting tubers with the lowest possible PVY incidence, growers attempt to isolate seed potato fields from fresh market or processing potato acreages. Early vine-killing is yet another PVY cultural management practice that effectively limits late-season aphids from landing within the field and spreading the virus. Other op- tions used for PVY control include planting resistant varieties, the use of border crops to clean the mouthparts (e.g., stylets) of both colonizing and noncolonizing aphids, and mineral oil sprays to limit aphid probing or feeding, which effectively inhibits virus transmission $(11,32)$. Insecticides have limited efficacy in controlling PVY since this stylet-borne virus is very quickly transmitted by aphids in a nonpersistent manner even on insecticide-treated plants. Although previously released, transgenic potatoes with resistance to PVY or other potato viruses are not currently used by or available to commercial growers in North America (21). While seed growers face rejection of lots and financial losses due to lost seed sales, farmers who grow potatoes for the fresh or processing markets can face significant yield losses if disease incidence ex-
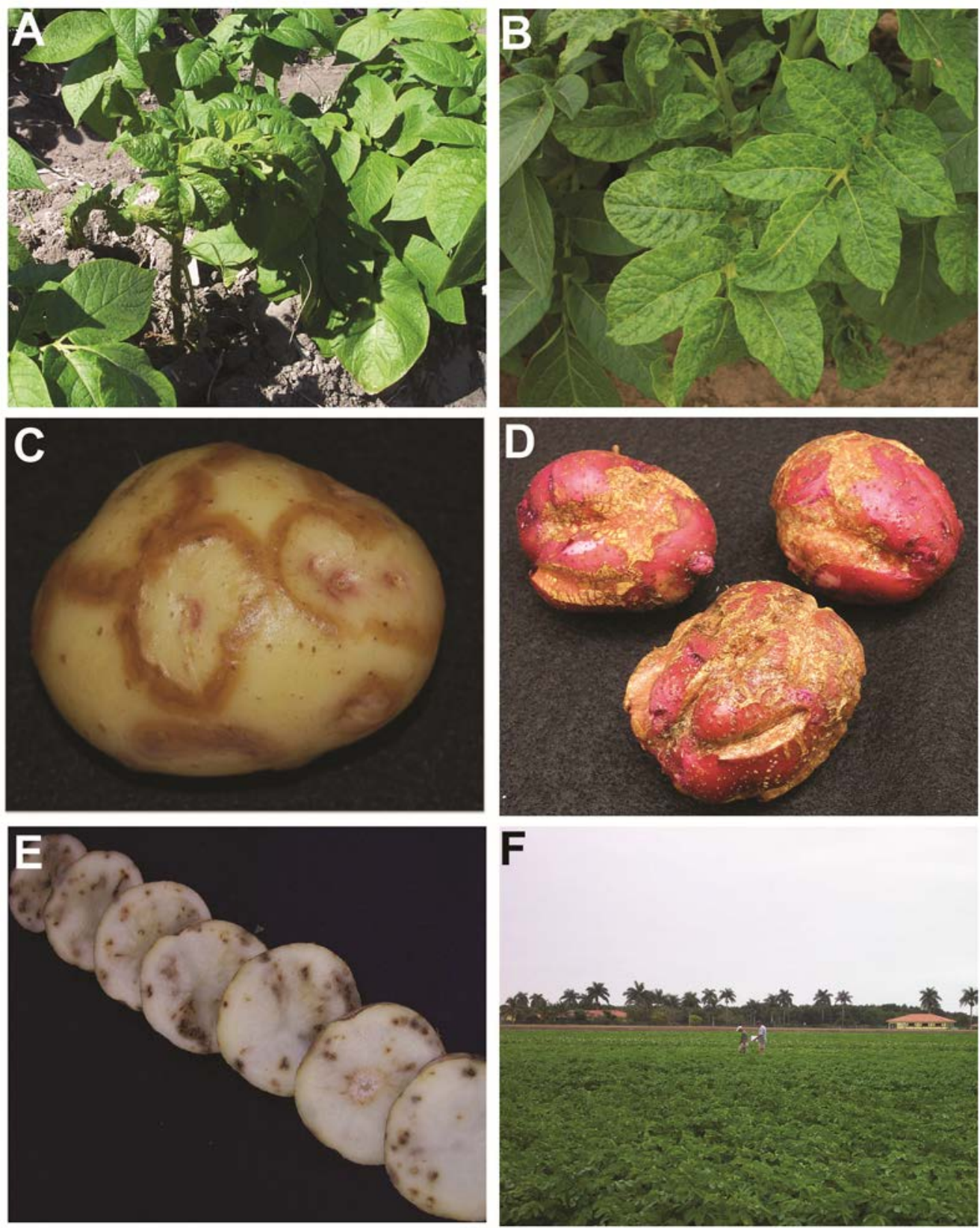

Fig. 2. Seed potato inspection consists of four critical inspections that control different diseases. Viral symptoms on plants grown from infected tubers are easiest to see in young plants, so potatoes are inspected within a month or two of planting to estimate the amount of viral infection carried over from the previous season. Virus symptoms can include rugosity and leaf drop (A), mosaic (B), and necrosis (not shown). Plants are inspected 90 days after planting for foliar bacterial ring rot symptoms. Next, the tubers are inspected at harvest or in storage for symptoms of necrotic viruses (C), bacterial decay, and other tuber-borne diseases. A necrotic Potato virus Y (PVY) strain on a Yukon Gold tuber is shown in C. Necrotic PVY strains are currently rare in Wisconsin, with only a few tubers such as this found on seed and commercial farms annually. Increase in incidence of this disease in the future is a concern. Conditions that affect tuber quality, such as herbicide damage (D) may also be found at harvest. Postharvest inspections are the most common time to find damaging soilborne diseases, such as spraing symptoms (E), which can be caused by Tobacco rattle virus or Potato mop top virus. Finally, a subset of tubers from each seed lot is planted each winter in a southern location, such as Florida, Hawaii, or California, and assayed visually $(\mathbf{F})$ and/or with laboratory assays to identify lots with variety mixtures, high disease incidence, or physiological problems that will impact the health of the crop grown from the seed lot. 
ceeds $10 \%$ in the seed they plant (29). In the past few decades, strains of PVY that cause necrotic symptoms in potato tubers have also become more prevalent $(4,5,14,18)$, leading to additional concern among growers that a high incidence of necrotic tuber symptoms in their crop will result in rejected shipments to processors and will inhibit trade.

Seed potato certification protocols. Historically, seed potato certification has relied almost entirely on visual inspections of the potato crop rather than laboratory assays. In Wisconsin, these inspections include an early summer inspection for viral and viroid diseases, a late summer inspection for bacterial ring rot, a harvest inspection for a wide range of diseases, and a postharvest, growout assay mainly for variety mixture and viral diseases (Fig. 2). During all inspections, potatoes are checked for variety mixture, other indications of errors in cultivation that may affect future crops, and other common, rare, and quarantine potato diseases. Routine laboratory testing is used for numerous pathogens when the plants are in tissue culture and for pathogen-variety-growth condition combinations that do not promote symptom development. For example, seed lots of potato varieties that do not exhibit clear symptoms when infected with PVY are assayed by enzymelinked immunosorbent assay (ELISA) after harvest to assess virus incidence. Inspection records are maintained in a database that records all observations relevant to pathogen incidence and varietal purity relevant to ATCP156. Details on how certification data are collected and maintained and how the data were analyzed for this article are described in the supplemental methods file.

The WSPCP records provide substantial data, collected through both the certification program and the Starks Farm, on pest and pathogen trends in an important agricultural crop. Similar longterm data sets for other crops that include production and financial data are rare and difficult or impossible to obtain. To examine the efficacy of seed potato certification over the past century, we initially take an approach that is broad in scope, but subsequently focuses on the more recent challenge of controlling PVY in the potato crop and discusses the potential utility of these program data.
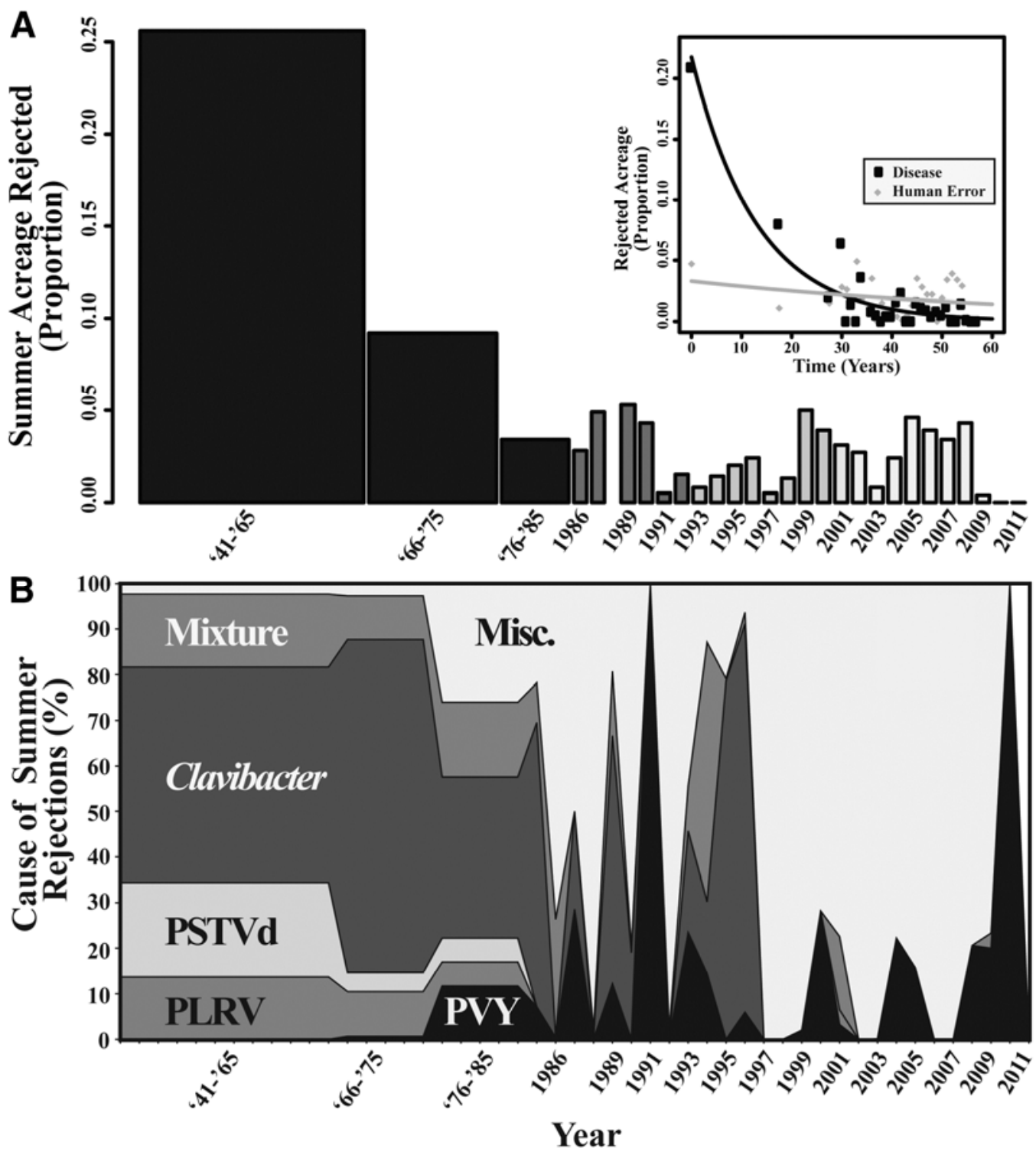

Fig. 3. Historical data from Wisconsin Seed Potato Certification Program summer inspections. A, Proportion of summer seed potato acreage rejected from certification from 1941 through 2010 in Wisconsin due to disease or human error. Data were taken from annual reports of the seed certification program and demonstrate a reduction in rejections that occurred over the course of several decades. The inset shows the fit of an exponential decay equation to: (1) proportion of summer rejected acreage due to disease (black dots and line: $\beta_{0}=0.01,|t|=0.2, P=N S ; \beta_{1}=-0.07,|t|=14.1, P<0.001$ ), and (2) proportion of lot rejections due to human error (gray dots and line: $\beta_{0}=$ $\left.-0.22,|t|=0.7, P=N S ; \beta_{1}=-0.02,|t|=2.1, P=0.04\right)$. These curves show that the decrease of rejections due to disease had a half-life of 9.8 years and due to human error had a half-life of 26.3 years. Causes of the summer rejections are shown (B) as a proportion of total rejections due to summer inspection data. These data show the reduction in importance of eliminating some pathogens, such as Potato spindle tuber viroid (PSTVd), from seed potato production, and the increase in importance of Potato virus $Y$ (PVY) in seed potato production. 
It is our goal to demonstrate the value of the practices adopted by the WSPCP to the potato industry as a means of inexpensive integrated control of potato pathogens, to provide suggestions about how the current system can be improved, and to predict future challenges.

The value of long-term data sets. The WSPCP's records provide substantial and long-term data on pest and pathogen trends that are difficult to obtain for many agriculturally important cropping systems. The consistent method of data collection helps to reduce the inherent variability often associated with long-term data sets, because these data were all obtained for the same purpose (26). The value of these long-term data is that they provide a range of observations in an agricultural system that allow us to determine if patterns of variability exist and if they can be correlated with changes in production practices, the environment, or the arrival of invasive species $(24,35)$. For example, these data contain points observed during circumstances that rarely occur, such as extreme weather or climactic conditions, and contain observations of seed potato production prior to and after pest and pathogen introductions. In the past, long-term seed potato data sets have been used to compare trends in pathogen prevalence with long-term environmental cycles such as drought, wildlife population sizes, and even sunspots $(2,3)$. Specific to our interests, these data provided empirical disease prevalence data to complement our narrative of the WSPCP, which despite recent challenges with PVY, has been an effectively designed and successfully implemented program to control pests and pathogens of potato. There is little doubt that agricultural science and policies over the past century have greatly impacted food production. Developing methods to generate similarly detailed long-term data for other cropping systems would greatly aid in assessing the long-term impacts and costs of pests and diseases, control methods, and policies and would likely aid us in developing more support for research in pest and disease control and appropriate policies to support food production.

Disease incidence in seed potatoes has decreased over time. For most of the twentieth century, PSTVd and C. michiganensis subsp. sepedonicus were the main reasons for rejection of seed potato lots. Control of these pathogens through production of a healthy seed supply and certification has resulted in a decrease in seed potato lots rejected during summer inspections (Fig. 3A). Initially, we were concerned with the integrity of the early data available in the WSPCP annual reports. Therefore, historical data from other sources were sought to corroborate the high levels of disease in the WSPCP records. Reports from the Potato Association of America, published in the 1940s and 1950s, similarly indicated that seed potato rejections across the United States resulted most often from infections of $C$. michiganensis subsp. sepedonicus. These estimates ranged from 0 to $31 \%$ per state, with annual averages ranging from 5 to $15 \%(8,41)$, which is similar to the levels reported by the WSPCP.

The proportion of summer rejected acreage due to disease was well described by the exponential decay model (Fig. $3 \mathrm{~A}$ inset: $\beta_{0}=$ $\left.0.01,|\mathrm{t}|=0.2, P=\mathrm{NS} ; \beta_{1}=-0.07,|\mathrm{t}|=14.1, P<0.001\right)$. Summer rejections due to pathogen/disease detection have decreased at a constant rate, with a half-life of about 9.8 years, suggesting a time horizon for the reduction of potato diseases following the inception of a seed program. The reduction in disease is presumably a combined result of improved, integrated pest management practices, extension education, and seed potato certification working to reduce inoculum levels. Notably, much of the initial reduction in disease incidence was prior to widespread use of potato tissue culture or laboratory assays, such as ELISA, for pathogen detection. Changes are unlikely to be due to improved varieties since some of the common varieties have been grown for decades. For example, Russet Burbank was released prior to the inception of the seed program, Red Norland was named and released in 1959 (20), Superior in 1962 (34), Yukon Gold in 1980, and Atlantic in 1978 (45). Several newly released varieties, such as Russet Norkotah in 1988 (19), are more susceptible to diseases of importance to seed potato certification than older varieties. None of the commonly grown varieties in the United States have resistance to C. michiganensis subsp. sepedonicus, PLRV, PVX, or PSTVd.

Seed potatoes are also certified for variety purity and general health, both of which can be compromised by human errors such as mistakes during harvest or planting that result in mixing multiple potato varieties in the same field or storage bin or pesticide misapplications that damage the crop. Summer rejections due to human error could also be described by the exponential decay model (Fig. 3A inset: $\beta_{0}=-0.22,|\mathrm{t}|=0.7, P=\mathrm{NS} ; \beta_{1}=-0.02,|\mathrm{t}|=2.1, P=$ 0.04 ), and the calculated half-life for summer rejections due to human error was 26.3 years. The reduction in error may be partially attributed to improved education of farmers through extension efforts and/or loss of farms that made repeated errors in seed potato production through dissolution of the business or focus on other crops. Farming is among the most dangerous of occupations, and human errors can lead to consequences far more serious than the downgrading of a seed potato lot. Even errors that do not result in injuries or death, such as misapplication of pesticides or variety mixtures, are costly since they often are not recognized until harvest, when fuel, land, and water resources have already been used. Human error now represents approximately $50 \%$ of the reasons for seed potato lot rejection, suggesting that there is a need for continued extension education and a need for agricultural research to be more integrated with the social sciences in order to identify methods for reducing on-farm errors.

Pathogen prevalence has changed over time. While the total percentage of summer-rejected seed potato lots has decreased over time, the prevalence of different pathogens has also changed (Fig. 3B). PSTVd was a significant problem during the first half of the 1900s, but the last recorded detection of PSTVd in the Wisconsin seed potato crop was in 1971. PSTVd is now considered to have been eradicated from the North American seed potato crop $(10,42)$.

Two potato viruses, aphid transmitted PLRV and mechanically transmitted PVX, also used to be widely prevalent and the cause of significant disease. The registration in the mid-1990s and subse-

Table 1. Number of plants and lots inspected in the winter and summer inspections (2002-2011) and the annual prevalence of Potato leafroll virus (PLRV) and Potato virus $Y$ (PVY)

\begin{tabular}{|c|c|c|c|c|c|c|c|c|}
\hline \multirow[b]{2}{*}{ Year } & \multicolumn{4}{|c|}{ Winter } & \multicolumn{4}{|c|}{ Summer } \\
\hline & Plants inspected & Number of lots & PLRV & PVY & Plants inspected & Number of lots & PLRV & PVY \\
\hline 2002 & 354,580 & 591 & 103 & 1,862 & $5,035,473$ & 507 & 64 & 3,888 \\
\hline 2004 & 310,565 & 506 & 11 & 999 & $4,658,318$ & 432 & 26 & 4,870 \\
\hline 2005 & 293,897 & 504 & 21 & 2,868 & $4,285,971$ & 450 & 15 & 2,315 \\
\hline 2006 & 301,297 & 492 & 2 & 1,146 & $4,173,475$ & 421 & 6 & 1,225 \\
\hline 2007 & 284,242 & 522 & 5 & 2,551 & $4,400,924$ & 440 & 0 & 3,639 \\
\hline 2008 & 304,206 & 564 & 0 & 1,817 & $4,183,691$ & 472 & 9 & 1,967 \\
\hline 2009 & 268,170 & 566 & 1 & 825 & $4,004,041$ & 470 & 0 & 1,334 \\
\hline 2010 & 191,823 & 460 & 0 & 307 & $4,399,270$ & 571 & 3 & 682 \\
\hline 2011 & 339,798 & 515 & 8 & 774 & $4,408,890$ & 515 & 1 & 357 \\
\hline
\end{tabular}


quent widespread use of systemic neonicotinoid insecticides, which target, among other insects, the potato-colonizing aphid species that serve as PLRV vectors (i.e., green peach aphid Myzus persicae Sulzer and potato aphid Macrosiphum euphorbiae Thomas), has greatly reduced PLRV incidence. Since 2006, only 19 of 25 million plants and 16 of 1.7 million plants inspected in the summer and postharvest, respectively, have been observed with PLRV symptoms (Table 1). In two of these five years, no leafroll symptoms were observed. A similar effect on virus levels was seen in the late 1940s when DDT was initially used to control a wide range of insects on potato, including the virus vectors (23). The low incidence of PLRV observed in the seed potato crop suggests that the PLRV detected in Wisconsin seed potatoes originates from outside these seed potato farms.

PVX incidence in the seed crop is harder to track since PVX symptoms are only evident when PVX and PVY co-infect potato, resulting in more severe symptom expression due to the synergistic action of the two viruses. Additionally, no systematic testing for PVX in field-grown potatoes is required as part of the Wisconsin seed certification program. In North America, all commercial potato production starts with PVX-free tissue culture plantlets, and because PVX is only mechanically transmitted its incidence is likely to remain low. From 1990 to 2000, a large number of plants grown on the Starks Farm were tested for PVX and other viruses after the first 2 years in the field (Table 2). All 500,000 plants tested during these 11 years were negative for PVX, confirming that during this decade the majority of the seed potato stock being planted in Wisconsin originated from PVX-free seed potatoes. Additionally, PVX was not detected from a sample of nine varieties from 20 different farms (2,100 plants in total) in the 2010 seed crop postharvest test (data not shown). In summary, PVX and PLRV incidence have dropped to nearly undetectable levels. The very low level of PVX over the past two decades suggests that eradication of this virus in North American potato production may be possible.

Similar to PVX, PVS presence in the seed crop is difficult to track since it remains latent in nearly all potato varieties, so visual identification of PVS-infected plants is usually not possible. In the Starks Farm survey, PVS infected the seed crop after only 1 year in the field, and this virus was found in 9 of the 11 years of the survey (Table 2). In 2010, PVS was detected by ELISA in 22 of 44 seed potato lots from a sample consisting of 2,100 plants or nine varieties obtained from 20 different farms (Table 3). Given that only two seed potato lots per farm were assayed for PVS, it is likely to be present on several seed potato farms in Wisconsin. Since PVS is widespread but does not usually cause foliar symptoms and since it is transmitted mechanically and by aphids (39), PVS would be difficult to control without deploying resistant varieties. Annual yield and raw product quality for seed potatoes in North America are among the highest worldwide, demonstrating that despite its prevalence, PVS is not a significant problem in seed potatoes.

Historically, bacterial ring rot, caused by $C$. michiganensis subsp. sepedonicus, was one of the largest disease problems facing seed potato certification. C. michiganensis subsp. sepedonicus was first described in Germany in 1906 (1) and was reported in the United States in 1932 (6). This vascular bacterial pathogen spreads effectively during seed cutting and may remain viable in bacterial slime dried on equipment or in warehouses for several years. It can remain latent in potato, with no symptoms exhibited for up to four consecutive crops $(13,22)$. When symptoms develop, $75 \%$ or more of the tubers may show symptoms in the field, and any tubers that are harvestable will not remain sound in storage. There are no curative treatments for plants infected with bacterial ring rot. Despite this, IPM practices that focused on plant indexing, inspections, and provision of healthy seed potatoes resulted in the near elimination of this pathogen from seed potato production in Wisconsin. The most recent detection of $C$. michiganensis subsp. sepedonicus in Wisconsin certified seed potatoes occurred in 1995 (Fig. 3B).

All potato varieties that are under widespread production are susceptible to PSTVd, PLRV, PVX, PVS, and C. michiganensis subsp. sepedonicus, and there are no on-farm curative treatments for these diseases. There is a zero tolerance for all potato pathogens in tissue culture. But of these four pathogens, there was a zero percent tolerance only for $C$. michiganensis subsp. sepedonicus in the field, starting in the 1940s, soon after it was first reported in North America. Tolerance levels for PLRV are as high as 5\% in

Table 3. Enzyme-linked immunosorbent assay (ELISA) results illustrating the number of composite lots positive for Potato virus $S$ (PVS) among the total lots sampled from the postharvest test in 2010

\begin{tabular}{lcc}
\hline Variety & $\begin{array}{c}\text { Lots positive for } \\
\text { PVS per lots tested }\end{array}$ & $\begin{array}{c}\text { Lots with greater } \\
\text { than } \mathbf{0 . 5 \%} \text { PVS }^{\mathbf{a}}\end{array}$ \\
\hline Dark Red Norland & $7 / 8$ & $5 / 8$ \\
Yukon Gold & $3 / 4$ & $3 / 4$ \\
Superior & $3 / 8$ & $2 / 8$ \\
Pike & $7 / 8$ & $6 / 8$ \\
Silverton & $0 / 3$ & $0 / 3$ \\
Russet Norkotah & $1 / 1$ & $1 / 1$ \\
Atlantic & $0 / 2$ & $0 / 2$ \\
Snowden & $0 / 3$ & $0 / 3$ \\
Goldrush & $2 / 7$ & $0 / 7$ \\
\hline a Composite samples were assayed; if two composite samples were
\end{tabular}

Table 2. Enzyme-linked immunosorbent assay (ELISA) results illustrating the number of infected plants from leaves collected after their first year (FY1) and second year (FY2) in the field at the Lelah Starks Certified Seed Potato Farma ${ }^{\mathrm{a}}$

\begin{tabular}{|c|c|c|c|c|c|c|c|}
\hline \multirow[b]{2}{*}{ Year } & \multicolumn{4}{|c|}{ FY1 } & \multicolumn{3}{|c|}{ FY2 } \\
\hline & Plants assayed & PVS & PVX & PVY & Plants assayed & PVX & $\mathbf{P V Y}^{\mathbf{b}}$ \\
\hline 1990 & 23,845 & 22 & 0 & 3 & 4,820 & 0 & $0 / 4,820$ \\
\hline 1992 & 36,510 & 149 & 0 & 0 & 11,100 & 0 & $0 / 4,200$ \\
\hline 1993 & 20,460 & 78 & 0 & 0 & 14,290 & 0 & $2 / 4,170$ \\
\hline 1994 & 26,180 & 51 & 0 & 0 & 19,200 & 0 & $0 / 4,000$ \\
\hline 1995 & 36,630 & 0 & 0 & 0 & 15,800 & 0 & $0 / 3,600$ \\
\hline 1996 & 30,960 & 0 & 0 & 0 & 17,600 & 0 & $0 / 4,000$ \\
\hline 1997 & 44,840 & 2 & 0 & 0 & 18,600 & 0 & $0 / 5,600$ \\
\hline 1998 & 36,200 & 6 & 0 & 0 & 19,600 & 0 & $0 / 400$ \\
\hline 1999 & 26,390 & 2 & 0 & 0 & 14,600 & $\mathrm{NT}^{\mathrm{c}}$ & $1 / 3,600$ \\
\hline 2000 & 28,400 & 12 & 0 & 0 & 16,400 & NT & $0 / 16,400$ \\
\hline
\end{tabular}

${ }^{a} \mathrm{PVS}=$ Potato virus $S, \mathrm{PVX}=$ Potato virus $X$, and $\mathrm{PVY}=$ Potato virus $Y$.

${ }^{\mathrm{b}}$ A subset of field year 2 leaves were tested for PVY.

c NT $=$ not tested. 
certified seed and, until 2007, were $1 \%$ for PSTVd. PVS and PVX do not have tolerances since certification is based on visual symptoms and these viruses do not cause symptoms in most potato varieties. In the case of potato, a seed potato certification program that propagates virus-free plant materials, requires planting of healthy materials, and eliminates infected seed lots is a crucial component to reducing current season spread of pathogens. For example, our data indicate that a clean seed source provided to growers combined with integrated plant protection strategies that control the spread of persistently transmitted viruses (e.g., PLRV) can reduce pathogen incidence to undetectable or nearly undetectable levels in the whole seed potato production system, even without zero tolerance.

The constancy of PVY. Mosaic disease, caused by PVY and first scientifically described in 1923 (37), has been a persistent problem in seed potato production since before the inception of seed certification programs in the United States. However, through most of the $1900 \mathrm{~s}$, its occurrence was overshadowed by the prevalence of PLRV, PSTVd, and C. michiganensis subsp. sepedonicus (Fig. 3B). In addition to persisting in seed potatoes and being mechanically transmitted by equipment, PVY is typically transmitted in a nonpersistent manner by numerous non-potato-colonizing aphid species and potato-colonizing species (i.e., $M$. persicae, $M$. euphorbiae) during the summer in the field. And because many non-colonizing aphid species are transient in the potato crop, insecticides have not been effective in reducing current season spread of PVY (14).

Although multiple PVY resistance genes have been found in potato (7), nearly all commercial potato varieties are susceptible to PVY. As a result, PVY is now the most common pathogen leading to the downgrading or rejection of seed potato acreage. In the summer and winter inspections combined (2002 to 2010), 93\% of downgrades or rejections of seed potato acreage due to a plant pathogen were cause by PVY infection, and 7\% were caused by other plant pathogens such as Pectobacterium (Fig. 4A). Over that same time period, approximately half of all rejected acres in summer and winter inspection were due to human errors including varietal mixture and pesticide misapplications.

Over the 20 years of data collected from the winter postharvest grow-out inspection test results, approximately $67 \%$ of the variation in the proportion of clean seed lots was associated with potato variety. More specifically, the proportion of clean seed lots varied among potato varieties, but the varietal responses were consistent among years (Fig. 4B). To examine the effect of variety, we cen-
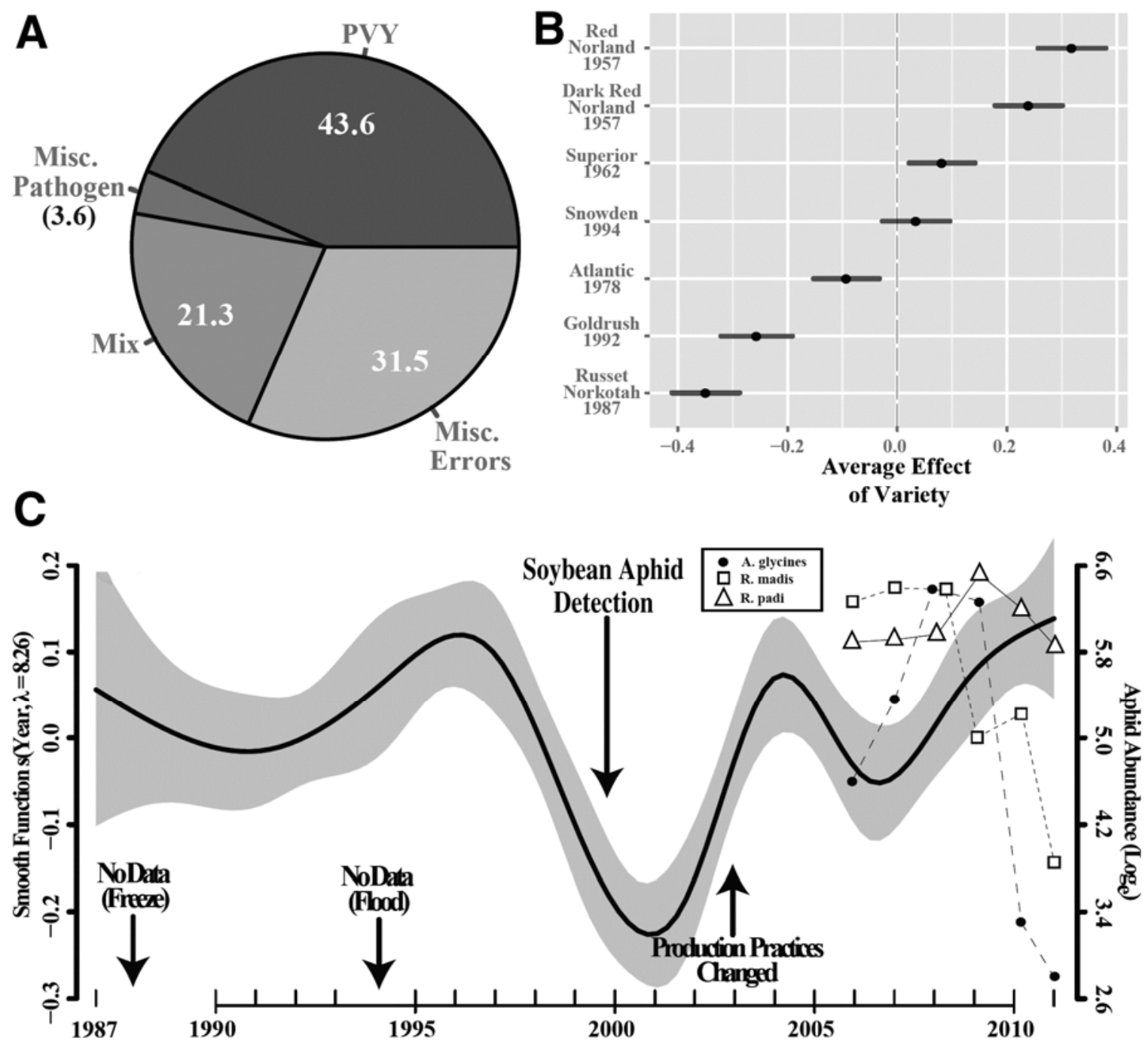

Fig. 4. A, Principal causes (\%) for seed potato acres rejected during summer and winter inspections combined (2002-2010) show that Potato virus $Y$ (PVY) causes approximately $50 \%$ of rejections and variety mixture and other human errors are responsible for most of the rest of the rejections. B, Potato varieties differ in susceptibility to PVY; some varieties are rarely rejected due to high PVY resistance. Parameter estimates \pm SE for seven popular potato varieties in which more than 10 lots were inspected per year from 1987 through 2011 in the Wisconsin Seed Potato Certification Program are shown in B. C, Proportion of seed lots rejected due to PVY increased in 1999, coincident with the arrival of the soybean aphid. Production changes implemented in 2003 may have aided in reducing rejection rates. The component smooth function for year representing the annual trend in the proportion of seed lots with no virus symptoms in the winter grow-out inspection among seven potato varieties is shown in C. Possible change points and cumulative sums of the three most abundant aphid species caught in the Antigo suction trap are also noted. 
tered the percentage of clean lots prior to modeling. A zero on the $\mathrm{x}$-axis represents the overall mean proportion of clean lots, and the effect of each variety was estimated as the difference from the mean (or zero). For example, Red Norland remained nearly virus free and had an average effect of 0.32 (90\% confidence interval [CI]: 0.26 to 0.39 ) (i.e., approximately 0.32 above the annual average proportion clean seed lots), while other varieties such as Russet Norkotah were more often PVY-infected and had average effect of -0.35 (90\% CI: -0.41 to -0.29 ). These results are consistent with Hamm et al. (16), who reported consistent differences among the response of eight potato cultivars to infection through current season spread of PVY.

The "consistently clean" phenotype might occur as a result of varietal klendusity combined with the inability of infected plants to produce tubers. For example, although the varieties Red Norland and Dark Red Norland are susceptible to PVY, they are relatively difficult to inoculate with PVY. However, once infected with the virus, the plant becomes stunted and often dies. Thus, few infected tubers are present in the subsequent generation. In contrast, Russet Norkotah is easily inoculated with PVY, but infected plants show few foliar symptoms and are not effectively rogued during the summer field inspections. Despite yield losses of up to $30 \%$ due to PVY infection, these varieties can produce many tubers, resulting in increased virus incidence in subsequent crops (29). Varieties such as Snowden and Atlantic have phenotypes that are intermediate and produce an average percentage of infected tubers that may be passed on to the next generation. These varietal phenotypic responses to infection with PVY appear to be consistent as evidenced by the narrow CI's (Fig. 4B), over 20 years in the current Wisconsin data set. These observations reaffirm the importance of cultivar selection and provide additional attributes for selection of varieties in breeding programs. For effective control of yield-limiting diseases, potato varieties should either be difficult to infect and if infected show severe symptoms, or they should be immune. Varieties that are susceptible, but that show mild or no foliar symptoms, should be avoided for vegetatively propagated crops. Marker-assisted selection tools are available for multiple different single dominant PVY resistance genes. Therefore, it should be possible for potato breeders to develop and release only varieties that are PVY-resistant and thereby eliminate the cause of $50 \%$ of seed potato rejections.

The effect of invasive species on PVY spread and translational research on PVY control. Approximately $14 \%$ of the variation in the proportion of clean seed lots, measured from the postharvest inspection, could be attributed to year (Fig. 4C). A visual examination of the plotted data suggested that the percentage of clean lots since 1998 has been more variable than for the previous 10 years. For example, the percentage of clean lots fell below the 20 -year average of 0.52 for the first time in 1999. It stayed below the 20-year average in 2000,2001, and 2002, but was again above average in 2005, 2009, and 2010. The variation in the proportion of

Table 4. Year effect on proportion of clean lots in the winter growout test and associated cumulative aphid numbers for the three most abundant aphid species captured in the Antigo suction trap

\begin{tabular}{lcccc}
\hline Year & $\begin{array}{c}\text { Seasonal } \\
\text { effect }\end{array}$ & $\begin{array}{c}\text { Aphis } \\
\text { glycines }\end{array}$ & $\begin{array}{c}\text { Rhopalosiphum } \\
\text { maidis }\end{array}$ & R. padi \\
\hline 2006 & -0.034 & 99 & 381 & 555 \\
2007 & -0.045 & 206 & 398 & 662 \\
2008 & 0.012 & 644 & 427 & 650 \\
2009 & 0.077 & 545 & 723 & 150 \\
2010 & 0.116 & 28 & 588 & 193 \\
2011 & 0.139 & 15 & 359 & 62 \\
& $R^{\text {a }}$ & -0.24 & 0.37 & -0.93 \\
& $P$ value $^{\mathrm{a}}$ & 0.65 & 0.46 & 0.007 \\
\hline
\end{tabular}

a Pearson's correlation coefficient and associated $P$ values calculated using $4 \mathrm{df}$. clean seed lots observed after 1998 is likely due to multiple causes, including such factors as changes in seed source, varieties grown, or changes in aphid vector abundance. For example, the introduction and establishment of the soybean aphid (Aphis glycines Matsumara) into Wisconsin was coincident with an observed reduction in the proportion of clean seed potato lots in 1999 and a few years thereafter. This insect annually undergoes a predictable, mass migration from infested soybean in midsummer, and these flights have been well-timed with the spread of Cucumber mosaic virus in susceptible snap bean and pepper crops in Wisconsin, as well as potato (27). We suspected that A. glycines contributed to the increased incidence of PVY symptoms observed in the winter growout tests. While the average proportion of clean seed lots did not change after the arrival of A. glycines (i.e., 1999 to 2010), it is interesting that the variability in the proportion of clean seed lots was higher after the aphid's arrival (Fig. 4C). For years when aphid data were available (2006 to 2010), we examined the correlation between the average annual model predictions, a measure of the average proportion of clean seed lots in each year, and the annual cumulative aphid captures for the three most abundant aphid species captured in the Antigo suction trap. We found that annual $A$. glycines abundance did not correlate to the average proportion of clean seed lots $(R=-0.23, t=0.49$, df $=4, P=0.65)$, nor did Rhopalosiphum maidis abundance $(R=0.37, t=0.81, \mathrm{df}=4, P=$ 0.46) (Table 4). However, Rhopalosiphum padi abundance was significantly correlated to the proportion of clean seed lots $(R=$ -0.93 , df $=4, P=0.007$ ). This result implies that the arrival and annual dispersal of $A$. glycines in Wisconsin does not appear to directly relate to the observed annual variation of PVY in seed potato. Moreover, $R$. padi, an aphid species often cited as the most important vector of PVY in other locations, appears to be a consistent problem. However, the effect of aphid abundance on the proportion of clean seed lots may occur as a lagged correlation, where high abundance affects the percentage of clean lots in the subsequent year or two. To detect this phenomenon would require more paired annual observations of aphid abundance and proportion of clean lots from the WSPCP than are currently available.

Changes to seed potato production practices might also explain, in part, the variability in PVY levels after 1998 and be partly responsible for the PVY reduction observed after 2003. For example, after noting the apparent increase of PVY incidence in Wisconsin on commercial seed farms and the state seed farm, the popular but highly susceptible varieties such as Russet Norkotah, Red LaSoda, and Silverton Russet were provided to growers after being grown for only 1 year in the field on the state farm rather than being grown for 2 years, which was previously the typical practice. To reduce the spread of virus from flying aphids, which may be attracted to field edges (11), seed potato fields were surrounded by spring-planted ryegrass or winter wheat, and fields were routinely sprayed with mineral oil. This was done in an attempt to reduce virus inoculum on the state farm and, subsequently, on seed potato farms throughout Wisconsin.

Utility of summer and winter grow-out inspection data. In general, the average virus incidence for a variety noted in the summer inspections was a good predictor of the amount of virus observed in the winter grow-out inspection (Fig. 5A). Our analysis indicated that separate regression slopes for each year were not necessary, but the best-fitting model that related summer inspections to winter inspections allowed the regression intercepts to vary among years (Table 5). This suggests that the experimental set of potato varieties responded consistently to PVY infection regardless of the virus pressure in the environment; a one-unit increase of PVY incidence measured in the summer inspections always resulted in a nine-unit increase of PVY incidence in the winter inspections. A possible hypothesis for this observation is that each PVY-infected plant produces, on average and across all varieties, nine infected tubers. However, virus pressure may vary among years since virus incidence in nearby commercial potato fields and aphid abundances vary, which similarly causes the average number of new plant infections (or the intercept value) to vary among years 
and ultimately affects the PVY incidence observed in the winter inspections. Thus, the parameters describing the varying intercepts for year may represent a measure of the relative magnitude of the current season spread of PVY.

Virus incidence measured in the winter inspections was also a good predictor of virus incidence observed in the subsequent summer inspection (Fig. 5B). However, in this case the best-fitting model that related winter inspections to summer inspections had a single slope and intercept; it was not necessary to fit separate slopes or intercepts by year because the relationship did not vary among years (Table 5). This suggests that the summer inspections are likely measuring the incidence of PVY that is seedborne and are not measuring PVY infections due to current season spread, possibly because disease symptoms resulting from new infections, which may typically occur late in the summer, do not have time to fully develop. Again, the set of potato varieties responded consistently to PVY infection and a one-unit increase of PVY incidence measured in the winter inspections resulted in a 0.003-unit increase of PVY incidence in the summer inspections. Thus, PVY incidence was lower in the summer crop than in the winter grow-out inspections. This could occur because PVY negatively affects tuber sprouting after a full winter of storage. However, it could simply be due to the fact that seed growers are selling seed lots with higher virus incidences and replanting only their cleanest seed lots. Regardless of the mechanism that drives this relationship, these data support the hypothesis that when low virus levels are observed in the winter postharvest inspection, there will be low virus levels in the subsequent crop.

In general, the WSPCP has been successful at producing high quality, pathogen-free potato seed with approximately $97 \%$ of all seed potato lots entered into the WSPCP from 2002 to 2011 being certified as either foundation or certified classification (Table 6). However, there is differential success among potato varieties in their ability to pass annual inspections (Table 6, Fig. 4). For example, over the last 10 years, approximately $99 \%$ of Red Norland and Superior seed lots have been certified with a high proportion of lots classified as foundation class. Yet varieties that are popular but highly susceptible to PVY, such as Russet Norkotah and Silverton Russet, have been less successful, with only 94 and $65 \%$ of all lots being certified, respectively, with lower percentages of lots certified as foundation class (Table 6). The reporting of this differential success among varieties may be useful information to growers to assist in making decisions about which potato varieties to grow to maximize their profit margin. For example, seed growers could use
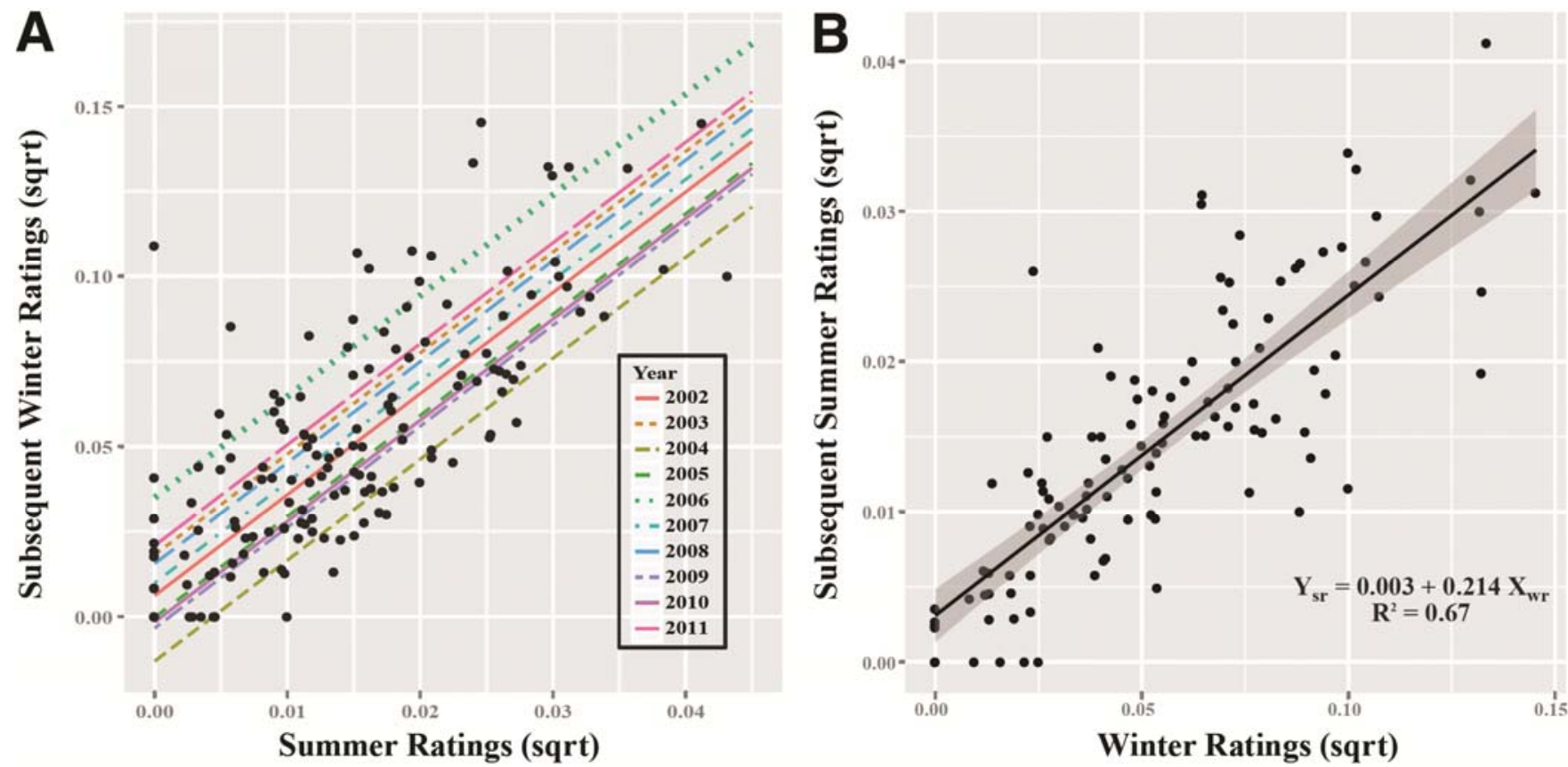

Fig. 5. Regression models relating Potato virus $Y$ (PVY) incidence in summer inspections to PVY incidence in the winter grow-out test. A, Relationship between PVY incidence in winter grow-out test and PVY incidence measured in the summer inspections. B, Relationship between PVY incidence measured in the summer inspections and PVY incidence measured in the preceding winter grow-out test.

Table 5. Analysis of variance (ANOVA) table for regression analysis relating Potato virus $Y$ (PVY) incidence in summer inspections to PVY incidence in the winter grow-out test and PVY incidence in the winter grow-out test to summer inspections in the subsequent year ${ }^{\mathrm{a}}$

\begin{tabular}{|c|c|c|c|c|c|c|c|}
\hline Independent variable & Parameters & df & $F$ value & $P$ value & df & $F$ value & $P$ value \\
\hline Winter inspections & $\begin{array}{l}\beta_{\mathrm{SI}}^{\mathrm{b}} \\
\beta_{\text {Year }} \\
\beta_{\mathrm{SI} \times \text { Year }}\end{array}$ & $\begin{array}{l}1,126 \\
9,126 \\
9,126\end{array}$ & $\begin{array}{r}36.2 \\
2.4 \\
0.7\end{array}$ & $\begin{array}{c}<0.001 \\
0.017 \\
0.72\end{array}$ & $\begin{array}{l}1,135 \\
9,135\end{array}$ & $\begin{array}{r}239.3 \\
7.5\end{array}$ & $\begin{array}{l}<0.001 \\
<0.001\end{array}$ \\
\hline Summer inspections ${ }^{c}$ & $\begin{array}{l}\beta_{\mathrm{WI}}^{\mathrm{d}} \\
\beta_{\text {Year }} \\
\beta_{\mathrm{WI}}\end{array}$ & $\begin{array}{l}1,100 \\
8,100 \\
8,100\end{array}$ & $\begin{array}{r}39.1 \\
1.4 \\
1.6\end{array}$ & $\begin{array}{c}<0.001 \\
0.20 \\
0.13\end{array}$ & $\begin{array}{l}1,108 \\
8,108\end{array}$ & $\begin{array}{r}163.5 \\
1.73\end{array}$ & $\begin{array}{c}<0.001 \\
0.10\end{array}$ \\
\hline
\end{tabular}

${ }^{a}$ Slopes and intercepts were originally allowed to vary among year, and models were simplified based on $F$ tests.

b SI = mean PVY incidence for a variety in the first summer inspection.

c Summer inspections were conducted in the year subsequent to winter inspections; final model was generalized and did not include separate intercepts for each year.

${ }^{\mathrm{d}} \mathrm{WI}=$ mean PVY incidence for a variety in winter grow-out inspection; final model was further reduced to include only a single intercept term. 
information about the probability of a lot of a specific variety being classified as foundation, certified, or rejected to estimate the expected monetary value of their crop. The probability of certification for a variety could be included, more formally, among the other factors influencing planting decisions. Additionally, the release of information about the performance of specific varieties may provide phenotypic targets for breeding programs or provide information that could be used in pedigree analysis.

Costs of controlling pathogens through seed potato certification. Over the past two decades, potato demand has not greatly changed, but yields have increased, resulting in a reduction in the average number of seed potato acres planted. Since farmer income is correlated with the hundred weight (cwt) of seed potato sold, we calculated the cost of certification, adjusted for inflation, per cwt of

Table 6. Cross tabulation of the classification of all lots and four selected potato cultivars after summer inspections and subsequent classification following the winter grow-out test $(2002-2011)^{\mathrm{a}}$

\begin{tabular}{|c|c|c|c|c|}
\hline \multirow[b]{2}{*}{ Variety } & \multirow[b]{2}{*}{ Summer class } & \multicolumn{3}{|c|}{ Winter class } \\
\hline & & $<0.5 \%$ & $0.5 \%<x<5 \%$ & $\geq 5 \%$ \\
\hline \multirow[t]{3}{*}{ Overall } & $<0.25 \%$ & $3166(80 \%)$ & $721(18 \%)$ & $82(2 \%)$ \\
\hline & $\begin{array}{c}0.25 \%<x<2 \% \\
\geq 2 \%\end{array}$ & $3(1 \%)$ & $302(91 \%)$ & $\begin{array}{c}27(8 \%) \\
15\end{array}$ \\
\hline & Totals & $3169(73 \%)$ & $1023(24 \%)$ & $131(3 \%)$ \\
\hline Red & $<0.25 \%$ & $208(99.5 \%)$ & $1(0.5 \%)$ & 0 \\
\hline \multirow[t]{2}{*}{ Norland } & $\begin{array}{c}0.25 \%<x<2 \% \\
\geq 2 \%\end{array}$ & 0 & 0 & $\begin{array}{l}0 \\
1\end{array}$ \\
\hline & Totals & $208(99 \%)$ & $1(0.5 \%)$ & $1(0.5 \%)$ \\
\hline \multirow[t]{3}{*}{ Superior } & $<0.25 \%$ & $246(86 \%)$ & $36(13 \%)$ & $3(1 \%)$ \\
\hline & $\begin{array}{c}0.25 \%<x<2 \% \\
\geq 2 \%\end{array}$ & 0 & $9(100 \%)$ & $\begin{array}{l}0 \\
0\end{array}$ \\
\hline & Totals & $246(84 \%)$ & $45(15 \%)$ & $3(1 \%)$ \\
\hline Russet & $<0.25 \%$ & $147(53 \%)$ & $118(42 \%)$ & $9(3 \%)$ \\
\hline \multirow[t]{2}{*}{ Norkotah } & $\begin{array}{c}0.25 \%<x<2 \% \\
\geq 2 \%\end{array}$ & 0 & $15(68 \%)$ & $\begin{array}{c}7(32 \%) \\
0\end{array}$ \\
\hline & Totals & $147(50 \%)$ & $133(45 \%)$ & $16(5 \%)$ \\
\hline Silverton & $<0.25 \%$ & $20(48 \%)$ & $18(43 \%)$ & $4(9 \%)$ \\
\hline \multirow[t]{2}{*}{ Russet } & $\begin{array}{c}0.25 \%<x<2 \% \\
\geq 2 \%\end{array}$ & 0 & $8(72 \%)$ & $\begin{array}{c}3(27 \%) \\
10\end{array}$ \\
\hline & Totals & $20(33 \%)$ & $23(38 \%)$ & $17(28 \%)$ \\
\hline
\end{tabular}

a Percentage of lots calculated based on the total number of lots classified in each category during summer inspections (calculated by row). potatoes tagged for sale. The cost of certification per cwt of potato has remained nearly the same over the last 20 years, adjusting for inflation, suggesting there has been no real cost increase based on fees paid to the WSPCP by seed growers (Table 7). Unlike many other costs associated with farming, such as the purchase of fuel, fertilizer, and pesticide, the fees associated with certification are typically returned to the local community through salaries paid to inspection staff and profits to the seed growers, and thus, benefit the local economy.

Although seed potato certification has always represented a significant cost in potato production, it appears to be cost-effective for controlling many seedborne pathogens, including many viral pathogens. When the WSPCP was started in 1914, growers paid one dollar per acre for the certification of eight or more acres of seed potato, which would be $\$ 22.96$ per acre in 2012 dollars. More recently, the cost (nominal) of seed potato certification on a per acre basis was, on average, $\$ 24$ per acre (Table 7). While the seed certification fees are paid by the seed growers, their costs are recovered through the sale of seed potatoes to farmers who produce crops for processing or table stock. The fees for certification, which effectively controls seedborne diseases, are relatively small compared to other costs incurred by potato farmers. It costs approximately $\$ 3,500$ to grow an acre of potatoes, with the majority of the costs incurred being in seed (\$235/acre, including seed cutting and seed treatments), fertilizer (\$307/acre), pesticides (\$105/acre), machinery (\$334/acre), storage (\$368/acre), labor (\$134/acre), and land and irrigation (\$390/acre) (31). Although a direct comparison is difficult to construct, the cost of seed certification, which controls diseases and quality, is low when compared to the costs associated with the implementation of a seasonlong plant protection and production program.

To our knowledge, there has been only one previous study that measured the economic value to growers of using pathogen-free planting materials (15). That 1991 study reported that the implementation of a law in 1981 requiring commercial potato growers to plant certified seed potatoes in Maine increased a typical commercial potato grower's profits by an average of $\$ 14,700$ per year for the years analyzed. In theory, for a single pathogen, it should be possible to estimate the value of the certification program to the average grower if there is a known relationship that relates disease incidence to yield, or yield loss. Then, a measure of the value of seed certification would result from the difference in expected value of yield given the probability of the different disease incidence that would occur with and without the existence of the seed

Table 7. Nominal and constant (1992 dollars) costs of seed potato certification expressed as dollars per acre and hundred weight (cwt)

\begin{tabular}{|c|c|c|c|c|c|c|c|}
\hline Year & Farms & Cwt & $\begin{array}{c}\text { Nominal } \\
\text { (\$/cwt) }\end{array}$ & $\begin{array}{c}\text { Constant } \\
\text { (\$/cwt) }\end{array}$ & Acres & $\begin{array}{l}\text { Nominal } \\
\left(\$ / \text { acre }^{a}\right)\end{array}$ & Constant (\$/acre) \\
\hline 1992 & 37 & $1,607,520$ & 0.13 & $\$ 0.13$ & 10,907 & $\$ 19.63$ & $\$ 19.63$ \\
\hline 1993 & 36 & $1,630,591$ & 0.14 & $\$ 0.13$ & 10,608 & $\$ 20.20$ & $\$ 19.63$ \\
\hline 1994 & 36 & $1,565,342$ & 0.12 & $\$ 0.11$ & 10,730 & $\$ 17.37$ & $\$ 16.41$ \\
\hline 1995 & 34 & $1,471,940$ & 0.13 & $\$ 0.12$ & 10,945 & $\$ 18.06$ & $\$ 16.57$ \\
\hline 1996 & 33 & $1,565,574$ & 0.15 & $\$ 0.13$ & 10,845 & $\$ 21.38$ & $\$ 19.02$ \\
\hline 1997 & 33 & $1,673,360$ & 0.14 & $\$ 0.12$ & 10,607 & $\$ 21.50$ & $\$ 18.67$ \\
\hline 1999 & 31 & $1,802,312$ & 0.14 & $\$ 0.11$ & 10,943 & $\$ 22.62$ & $\$ 18.92$ \\
\hline 2000 & 31 & $1,551,102$ & 0.17 & $\$ 0.14$ & 10,828 & $\$ 24.20$ & $\$ 19.57$ \\
\hline 2001 & 30 & $1,526,315$ & 0.19 & $\$ 0.15$ & 10,517 & $\$ 26.45$ & $\$ 20.83$ \\
\hline 2002 & 29 & $1,540,927$ & 0.19 & $\$ 0.15$ & 10,452 & $\$ 26.89$ & $\$ 20.92$ \\
\hline 2003 & 28 & $1,314,639$ & 0.24 & $\$ 0.18$ & 9,312 & $\$ 28.53$ & $\$ 21.78$ \\
\hline 2004 & 27 & $1,233,740$ & 0.23 & $\$ 0.17$ & 8,504 & $\$ 25.51$ & $\$ 19.01$ \\
\hline 2005 & 26 & $1,461,030$ & 0.18 & $\$ 0.13$ & 8,489 & $\$ 24.37$ & $\$ 17.60$ \\
\hline 2006 & 26 & $1,321,151$ & 0.20 & $\$ 0.14$ & 8,625 & $\$ 24.37$ & $\$ 17.19$ \\
\hline 2008 & 27 & $1,444,108$ & 0.20 & $\$ 0.13$ & 8,302 & $\$ 26.67$ & $\$ 17.67$ \\
\hline 2009 & 25 & $1,678,542$ & 0.18 & $\$ 0.12$ & 8,163 & $\$ 27.54$ & $\$ 18.37$ \\
\hline 2010 & 25 & $1,691,231$ & 0.20 & $\$ 0.13$ & 8,133 & $\$ 30.64$ & $\$ 20.04$ \\
\hline
\end{tabular}

${ }^{a}$ Cost adjusted for the decrease in acreage using the 19-year average acreage. 
certification program. Unfortunately, information about the probability of diseases occurring with and without a seed certification program is difficult to obtain. Losses due to plant diseases are also difficult to obtain since multiple diseases occur simultaneously, plants neighboring diseased plants compensate yields in part by yielding more than average in the field, and diseases may result in the produce being sold in a different market for a lower price, which is difficult to track.

To value a seed program based only on the value of yield increase due to the provision of pathogen-free planting materials ignores other values of the program. For example, a significant value of certification and foundation seed production programs includes the infrastructure required to protect against or combat future introductions of invasive pests or pathogens and a mechanism for farmers and researchers to cooperatively identify and solve production challenges. Even if the cost of operating a seed certification program outweighs the benefits for the industry in an average year, it still makes economic sense to maintain the program because it insures the industry against the occurrence of a catastrophic, but low probability event. Additionally, processing plants typically demand a steady supply of raw product, and the value of a seed certification program, in a related sense, could come from steadying supply and reducing seed potato price volatility by lowering the probability of a crop or a postharvest storage failure. Finally, there may be a value in having established market chains to deploy improved cultivars and diversify the crop production portfolio.

Having an understanding of the value of a seed certification program and an idea of the time horizon over which a seed certification program may have impact, will be useful for determining how much capital investment is warranted for the development of seed certification and disease-free planting material programs, particularly for countries currently expanding their agricultural infrastructure. In the United States, there is opportunity for studying the social and economic aspects of seed production systems, and closer collaboration between economists, sociologists, and plant scientists is necessary to better understand the value associated with the provision of disease-free planting materials.

Factors that contributed to seed program stability. Seed potato programs blossomed across North America a century ago and are still in place in Canada and all major seed potato producing states in the United States despite major changes in agriculture, such as the invention of tractors, synthetic fertilizers, and pesticides, and the consolidation of many agricultural supply companies. The WSPCP consists of an early generation production system, which runs essentially like a cooperative that serves approximately 25 family farms, and a voluntary regulatory program aimed to provide a consistently healthy seed potato supply. The cooperative nature of this program allows these family farms to control the quality and amount of their seed supply, and the close relationship with the university simplifies technology transfer. This is a distinct contrast to the seed production of other major crops, such as maize and soybean, which have been consolidated under the control of a few large multinational corporations over the past two decades. In addition to control over their own seed supply, the long-term data collection on disease incidence, disease control costs, and potato production aids in development of policies by the seed potato farmers. Together, these attributes have likely contributed to the long-term stability of the Wisconsin seed potato industry and the WSPCP.

The challenges and charge for the seed potato program in the future. The WSPCP was founded in 1913 with the two primary goals of reducing pathogen incidence and of providing seed of varieties with known characteristics in order to increase industry productivity. In the 100 years that followed its foundation, the WSPCP has, in large part, accomplished those goals. The last recorded incidence of PSTVd in the Wisconsin seed potato crop was in 1971, PLRV and PVX currently exist at extremely low levels, and $C$. michiganensis subsp. sepedonicus has not been detected in the WSPCP for almost two decades. In general, the existence of the
WSPCP and other certifying institutions has produced a potato crop that is free of many of the formerly prevalent infectious diseases of potato. Just as a community free of infectious diseases due to a high vaccination rate can be viewed as common $(17,25)$, so the existence of a disease-free potato crop can also be viewed as a common. The very existence of this disease-free "potato common" might imply that there is tension between the best interests of individual stakeholders and the best interests of the potato industry as a whole. However, the WSPCP represents an example of cooperation between multiple members of the potato industry who participate in and support the seed potato certification process, suggesting there are shared long-term benefits for many industry stakeholders involved in potato production. Although virus-resistance incorporated into potato varieties using traditional breeding or transgenic technologies would allow further reduction of virus levels, in our judgment, a seed certification system will remain important for the production of high quality disease-free planting materials (40).

Many new challenges in seed potato production will not be easily solved by genetic modification of plants or traditional plant breeding. Those challenges include the increased movement of seed potatoes, resulting in increased movement of difficult-tocontrol soilborne pathogens, such as potato cyst nematode (Globodera sp.) and powdery scab (Spongospora subterranean); the emergence of new pests and pathogens, such as 'Candidatus Liberibacter solanacearum', which causes zebra chip; and finally climate change, which will expand the host range of existing pests and pathogens and decrease predictability of season length and water availability for crop production. Cooperative seed production programs that combine the efforts of farmers and researchers to stabilize seed production and prices have aided in identifying the magnitude of each of these challenges and will also aid in management of these complex problems.

\section{Acknowledgments}

We thank Robert Coltman for designing and maintaining the WSPCP database. We also thank Richard Hafner, Kevin Bula, Dianna Kessler, and James Meyers for inspecting millions of potato plants, and Henry Darling, Steven Slack, Thomas German, Walt Stevenson, and Douglas Maxwell for guidance of the WSPCP from 1941 through 2001. We thank Jason Frost for useful discussions about the value of a seed certification program and Chris McIntosh and Stewart Gray for helpful reviews of our manuscript. Finally, we thank J. G. Moore, H. L. Russell, W. A. Orton, W. Stuart, J. W. Brann, J. W. Hicks, L. R. Jones, and the Wisconsin seed potato farmers for having the foresight to establish a seed potato certification program in 1913 and Lelah Starks for providing the funds for a foundation seed potato farm in Wisconsin. Funding support was provided by USDA-SCRI project 2009-02768.

\section{Literature Cited}

1. Appel, O. 1906. Neuere untersuchungen über kartoffel und tomatenerkrankungen. Jahresbericht der Vereinigung für angewandte Botanik 3 (132-135).

2. Bagnall, R. H. 1988. Epidemics of potato leafroll in North America and Europe linked to drought and sun spot cycles. Can. J. Microbiol. Plant Pathol. 10:193-202.

3. Bagnall, R. H. 1992. Epidemiology of potato virus Y in New Brunswick, Canada; a biennial rhythm and a 9-plus year cycle. Can. J. Plant Pathol. 14:137-146.

4. Baldauf, P. M., Gray, S. M., and Perry, K. L. 2006. Biological and serological properties of Potato virus $\mathrm{Y}$ isolates in northeastern United States potato. Plant Dis. 90:559-566.

5. Beczner, L., Horváth, H., Romhányi, I., and Förster, H. 1984. Studies on the aetiology of tuber necrotic ringspot disease in potato. Potato Res. 27:339352.

6. Bonde, R. 1937. A bacterial wilt and soft rot of the potato in Maine. Phytopathology 27:106-108.

7. Bradeen, J. M., and Kole, C. 2011. Genetics, Genomics and Breeding of Potato. CRC Press, Boca Raton, FL.

8. Darling, H. M. 1948. Ring rot survey. Am. Potato J. 25:44-47.

9. De Boer, S. H., and Boucher, A. 2011. Prospect for functional eradication of the bacterial ring rot disease of potato. Can. J. Plant Pathol. 33:297-307.

10. De Boer, S. H., Xu, H., and DeHaan, T. L. 2002. Potato spindle tuber viroid not found in western Canadian provinces. Can. J. Plant Pathol. 24:372-375.

11. Difonzo, C. D., Ragsdale, D. W., Radcliffe, E. B., Gudmestad, N. C., and 
Secor, G. A. 1996. Crop borders reduce potato virus Y incidence in seed potato. Ann. Appl. Biol. 129:289-302.

12. Foster, G. D. 1991. Molecular variation between ordinary and Andean strains of Potato virus S. Res. Virol. 142:413-416.

13. Franc, G. D. 1999. Persistence and latency of Clavibacter michiganensis subsp. sepedonicus in field-grown seed potatoes. Plant Dis. 83:247-250.

14. Gray, S. M., De Boer, S. H., Lorenzen, J. H., Karasev, A. V., Whitworth, J., Nolte, P., Singh, R., Bouche, A., and Xu, H. 2010. Potato virus Y, an evolving concern for potato crops in the United States and Canada. Plant Dis. 94:1384-1397.

15. Guenthner, J. F., Plissey, E. S., Levi, A. E., and Makus, L. D. 1991. The impact of the mandatory seed law on Maine potato acreage, yield, and price. Am. Potato J. 68:381-390.

16. Hamm, P. B., Hane, D. C., Pavek, M. J., Leroux, L. D., Gieck, S. L., and David, N. L. 2010. Potato cultivars differ in current season potato virus Y (PVY) infection. Am. J. Potato Res. 87:19-26.

17. Hardin, G. 1968. The tragedy of the commons. Science 162:1243-1248.

18. Jakab, G., Droz, E., Brigneti, G., Baulcombe, D., and Malnoe, P. 1997. Infectious in vivo and in vitro transcripts from a full-length cDNA clone of PVY-N605, a Swiss necrotic isolate of potato virus Y. J. Gen. Virol. 78:3141-3145.

19. Johansen, R. H., Farnsworth, B., Nelson, D. C., Secor, G. A., Gudmestad, N., and Orr, P. H. 1988. Russet Norkotah: A new russet-skinned potato cultivar with wide adaptation. Am. J. Potato Res. 65:597-604

20. Johansen, R. H., Sandar, N., Hoyman, W. G., and Lana, E. P. 1959. Norland, a new red-skinned potato variety with early maturity and moderate resistance to common scab. Am. Potato J. 36:12-15.

21. Kaniewski, W. K., and Thomas, P. E. 2004. The potato story. AgBioForum 7:41-46

22. Kawchuk, L. M., Lynch, D. R., Kozub, G. C., Nelson, G. A., Kulscar, F., and Fujimoto, D. K. 1998. Multi-year evaluation of Clavibacter michiganensis subsp. sepedonicus disease symptoms in cultivated potato genotypes. Am. J. Potato Res. 75:235-243.

23. King, L. W. 1952. Washington certified seed potatoes. Am. Potato J. 29:5354

24. Magnuson, J. T. 1990. Long-term ecological research and the invisible present. Bioscience 40:495-501.
25. Malone, K. M., and Hinman, A. R. 2003. Vaccination mandates: The public health imperative and individual rights. Pages 262-284 in: Law in Public Health Practice, R. A. Goodman, R. E. Hoffman, W. Lopez, G. W. Matthews, M. A. Rothstein, and K. L. Foster, eds. Oxford University Press, New York.

26. Manly, B. F. J. 1998. Sampling and modeling of insect populations. Pages 3-20 in: Population and Community Ecology for Insect Management and Conservation. J. Baumgartner, P. Brandmayr, and B. F. J. Manly, eds. A. A Balkema Publishers, Brookfield, VT.

27. Mueller, E. E., Frost, K. E., Esker, P. D., and Gratton, C. 2010. Seasonal phenology of Aphis glycines (Hemiptera: Aphididae) and other aphid species in cultivated bean and noncrop habitats in Wisconsin. J. Econ. Entomol. 103:1670-1681.

28. Nelson, G. A. 1982. Corynebacterium sepedonicum in potato: Effect of inoculum concentration on ring rot symptoms and latent infection. Can. J. Plant Pathol. 4:129-133.

29. Nolte, P., Whitworth, J., Thornton, M. K., and McIntosh, C. S. 2004. Effect of seedborne Potato virus Y on performance of Russet Burbank, Russet Norkotah, and Shepody potato. Plant Dis. 88:248-252.

30. Owens, R. A. 2007. Potato spindle tuber viroid: The simplicity paradox resolved? Mol. Plant Pathol. 8:549-560.

31. Patterson, P. 2010. Costs of Production. In: Commercial Potato Production in North America. W. H. Bohl and S. B. Johnson, eds. The Potato Association of America.

32. Powell, G., Hardie, J., and Pickett, J. A. 1998. The effects of antifeedant compounds and mineral oil on stylet penetration and transmission of potato virus Y by Myzus persicae (Sulz.) (Hom., Aphididae). J. Appl. Entomol.-Z. Angew. Entomol. 122:331-333.

33. Radcliffe, E. B., and Ragsdale, D. W. 2002. Aphid-transmitted potato viruses: The importance of understanding vector biology. Am. J. Potato Res. 79:353-386.

34. Rieman, G. H. 1962. Superior: A new white medium-maturing scab-resistant potato variety with high chipping quality. Am. Potato J. 39:19-28.

35. Sagarin, R., and Pauchard, A. 2010. Observational approaches in ecology open new ground in a changing world. Front. Ecol. Environ. 8:379-386.

36. Scholthof, K. B. G., Adkins, S., Czosnek, H., Palukaitis, P., Jacquot, E., Hohn, T., Hohn, B., Saunders, K., Candresse, T., Ahlquist, P., Hemenway,

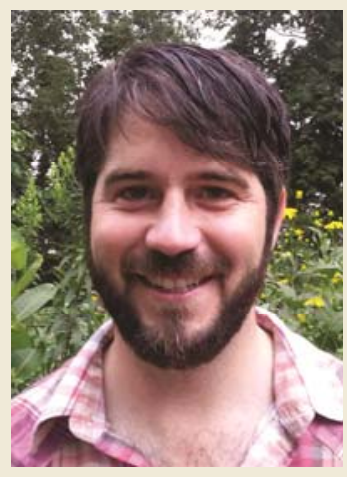

Kenneth E. Frost

Dr. Frost is a postdoctoral research associate splitting time between the plant pathology and entomology departments at the University of Wisconsin-Madison. $\mathrm{He}$ received his M.S. and Ph.D. in plant pathology from the University of Wisconsin-Madison. His current work focuses on implementing and optimizing weatherbased pest and disease forecasting models to inform and enhance management of vegetable crops grown in Wisconsin. His research interests are directed toward improving integrated pest management programs and include the ecology and epidemiology of insect-vectored pathogens, mathematical biology and ecological modeling, and the economics of pest and disease suppression.

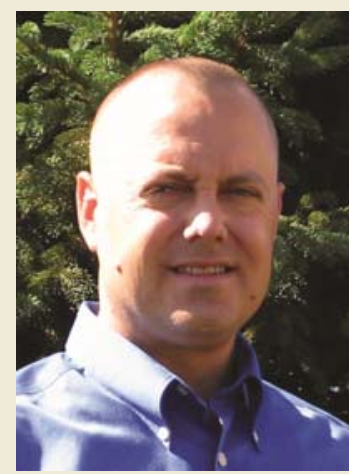

Russell L. Groves

Dr. Groves is an associate professor in the Department of Entomology at the University of Wisconsin-Madison, with a majority of his effort devoted to Vegetable Pest Management Extension, where he has responsibilities for both commercial and fresh market vegetables. He received his M.S. in entomology from the University of Arkansas and his Ph.D. in entomology from North Carolina State University. His research focus is on the development of integrated pest management systems for vegetable crops and applied insect ecology with an emphasis on insect vector-borne disease epidemiology, insect dispersal and movement and insecticide resistance management.

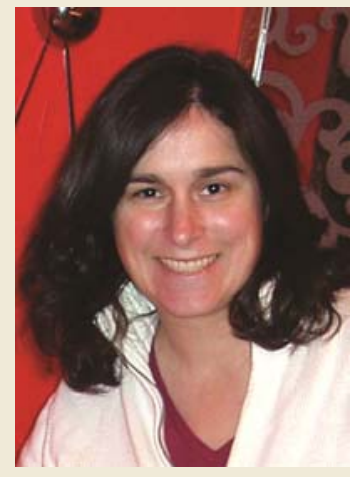

\section{Amy O. Charkowski}

Dr. Charkowski is a professor in the Department of Plant Pathology and the administrative director of the Wisconsin Seed Potato Certification Program. She received her Ph.D. in plant pathology from Cornell University. Her research focuses on the control of bacterial and viral diseases that impact seed potato production, including control of Potato virus $Y$ and bacterial soft rot. Her research group also works on optimization of potato tissue culture and early generation potato production methods. 
C., and Foster, G. D. 2011. Top 10 plant viruses in molecular plant pathology. Mol. Plant Pathol. 12:938-954.

37. Schulz, E. S., and Folsom, D. 1923. Transmission, variation, and control of certain degeneration diseases of Irish potatoes. J. Agric. Res. 25:43-117.

38. Skryabin, K. G., Kraev, A. S., Morozov., S. Y., Rozanov, M. N., Chernov, B. K., Lukasheva, L. I., and Atabekov, J. G. 1988. The nucleotide sequence of Potato virus X RNA. Nucleic Acids Res. 16:10929-10930.

39. Slack, S. A. 1983. Identification of an isolate of the Andean strain of potato virus $\mathrm{S}$ in North America. Plant Dis 67:786-789.

40. Slack, S. A., and German, T. L. 1998. Impact of transgenic viral resistance on seed potato certification. Am. J. Potato. Res. 75:265-268.

41. Starr, G. H. 1957. Potato ring rot information (as determined by a recent survey). Am. Potato J. 34:264-268.

42. Sun, M., Susan Siemsen, S., Campbell, W., Guzman, P., Davidson, R., Whitworth, J. L., Bourgoin, T., Axford, J., Schrage, W., Leever, G., Westra, A., Marquardt, S., El-Nashaar, H., McMorran, J., Gutbrod, O., Wessels, T., and Coltman, R. 2004. Survey of Potato Spindle Tuber Viroid in seed potato growing areas of the United States. Am. J. Potato Res. 81:227-231.

43. Taliansky, M., Mayo, M. A., and Barker, H. 2003. Potato leafroll virus: A classic pathogen shows some new tricks. Mol. Plant Pathol. 4:81-89.

44. van der Wolf, J. M., van Beckhoven, J. R. C. M., Hukkanen, A., Karjalainen, R., and Muller, P. 2005. Fate of Clavibacter michiganensis ssp. sepedonicus, the causal organism of bacterial ring rot of potato, in weeds and field crops. J. Phytopathol. 153:358-365.

45. Webb, R. E., Wilson, D. R., Shumaker, J. R., Graves, B., Henninger, M. R. Watts, J., Frank, J. A., and Murphy, H. J. 1978. Atlantic: A new potato variety with high solids, good processing quality, and resistance to pests. Am. Potato J. 55:141-145.

46. Whitworth, J., and Davidson, R. D. 2008. Quality seed: Seed improvement, cultivar and seed lot selection, and certification. Pages 31-41 in: Potato Health Management. D. A. Johnson, ed. American Phytopathological Society, St. Paul, MN. 